Article

\title{
Aesthetics as a Philosophical and Theological Space in the St. Francis of St. Bonaventure's Major Legend
}

\author{
Manuel Lázaro Pulido 1,2,*(D) and Esteban Anchústegui Igartua ${ }^{3, *(D)}$ \\ 1 Department of Public Law, Universidad Internacional de La Rioja-UNIR, 26006 Logroño, Spain \\ 2 Department of Sciences Law, Universidad Bernardo O'Higgins, Santiago 8370993, Chile \\ 3 Department of Philosophy of Values and Social Anthropology, Universidad del País Vasco UPV/EHU, \\ 20018 Donostia-San Sebastián, Spain \\ * Correspondence: manuel.lazaro@unir.net (M.L.P.); esteban.antxustegi@ehu.eus (E.A.I.); \\ Tel.: +34-636-037-688 (M.L.P.)
}

Citation: Lázaro Pulido, Manuel, and Esteban Anchústegui Igartua. 2022. Aesthetics as a Philosophical and Theological Space in the St. Francis of St. Bonaventure's Major Legend. Religions 13: 114. https://doi.org/ 10.3390/rel13020114

Academic Editor:

Brandon Vaidyanathan

Received: 6 November 2021

Accepted: 22 January 2022

Published: 24 January 2022

Publisher's Note: MDPI stays neutral with regard to jurisdictional claims in published maps and institutional affiliations.

Copyright: (C) 2022 by the authors. Licensee MDPI, Basel, Switzerland. This article is an open access article distributed under the terms and conditions of the Creative Commons Attribution (CC BY) license (https:// creativecommons.org/licenses/by/ $4.0 /)$.

\begin{abstract}
This paper demonstrates that the figure of St. Francis of Assisi, as expounded by St. Bonaventure in his work Legenda Major (Major Legend), cannot be understood without certain philosophical and theological keys. Following an expository methodology, we point to Saint Francis as a theological aesthetic model. In this sense, we focus on five characterisations found in the Major Legend, introducing their aesthetic meaning, as well as the philosophical and theological significance of St. Bonaventure. We refer to St. Francis as a contemplator of nature, lover of poverty, an imitator of the crucified Christ, a brother of humankind and a Lord's knight and minstrel, to conclude that the aesthetic model of St. Francis, as found in St. Bonaventure, can only be understood starting from theological (mystical) and philosophical ascension.
\end{abstract}

Keywords: St. Francis of Assisi; St. Bonaventure; Major Legend; aesthetics; medieval theology; Franciscanism; mysticism

\section{Introduction}

In this paper, we attempt an aesthetic approach to St. Francis as found in St. Bonaventure's work Major Legend (Legenda Major) as an expression of philosophical and theological rationality, that is, from the philosophy of religion.

It is important to note that recovering medieval aesthetic thought is not a new practice. Brilliant approaches abound both from the perspective of Christian thought-where classics have already been written on the subject, such as the studies of Edgar Bruyne (1947) and Umberto Eco $(1986,2009)$ - and from that of Arab thought (Puerta 1997; Gonzalez 2001). Lomba spoke of the wealth of nuances and questions contained in this aesthetic theme: "It is a subject which, on the one hand, is highly expressive of the medieval spirit and, on the other, covers a multitude of aspects, not only metaphysical, religious, political and social, but also invites comparative reflection on the multiple aesthetics of the Middle Ages: Christian, Muslim and Jewish" (Lomba 1999, p. 7). Therefore, studies on the thought of the Seraphic Doctor also include a reflection on aesthetics.

Medieval aesthetics is proposed as a glorious path that looks more deeply into created nature in order to reach the source of beauty. Within this framework, religion is an intentional call to penetrate the primacy of reality. Religious aesthetics manifests itself, then, as the space where being is practiced, a metaphysical manifestation that surpasses the ontological limit, which is restricted to the mundane. The intimacy of reality is an epiphany, a divine manifestation with full freedom and without conceptual limits. From this representative, significant perspective, one can observe the depth of the sensible realm, as well as the permanence of movement as manifested in generation and corruption. The world is thus understood as aesthetic, rather than anti-static, insofar as it is the expression of God's imprint. The world is no longer worldly, but rather a temporal hierophany. The human 
being presents himself as an aesthetic being capable of finding beauty (capax pulchri), for only the person, as Thomas Aquinas writes in Summa Theologica I, 91.3 ad 3 (Aquinas [1265] $1889,394 a$ ), delights in the beauty of the sensible order for the sake of beauty itself (Solus homo delectatur in ipsa pulchritudine sensibilium secundum seipsam).

In the Middle Ages, this aesthetic regard for the created world took on greater significance in hagiographic aesthetics. As Veyrard-Cosme (2003) has shown, the early medieval Vitae, which contain aesthetic repetition, show how psalmodic melody allows the saint's praise to become God's praise. The generic term Vita, understood in the eschatological sense of New Life, thus becomes less of a biographical effort to recount an eponymous hero's journey and more of a spiritual itinerary for anonymous recipients. In this context, St. Bonaventure wrote Major Legend, a biography of St. Francis. The lives of the saints point to lived humanism as a valid itinerary for the development of the thoughtful humanism that is so necessary in times of post-human vulnerability (Liedo and Rueda 2021). It is an ascending way of describing the human being, his affinities with the various degrees of being, and the differences that separate him from all other beings. When his difference is grasped, so too is the essence of the human being (Lobato 1999, p. 60); thus, as a microcosm, he has the gift of intensely and truly uniting what is dispersed in the macrocosm. The Major Legend develops as a Vita that transforms hagiography into an aesthetic experience capable of penetrating the depths of reality and expressing a mystical itinerary, thus surpassing the brevity of basic hagiographic writing (Lambert 2017, p. 508). It retains, moreover, a certain liturgical tone that is also characteristic of hagiographic language (Goullet 2011), bearing in mind that liturgy is an aesthetic manifestation of the divine mystery.

In this sense, rather than focusing on a controversy surrounding the aesthetic of the philosophy of religion, this study aims to highlight the medieval innovation of introducing a hagiographic language with philosophical and theological depth through the aesthetics introduced with the figure of St. Francis. This innovation impacts access to the divine mystery, thus serving as an example of what Von Balthasar meant by the term "theological aesthetics" (Balthasar 1962).

The question of beauty is present in theological reflection in so far as it is one of the constitutive features of God, one of his transcendentals. Beyond this metaphysical-aesthetic perspective, a theological view of aesthetics transforms the very conception of aesthetics in the sense that beauty is related to the iconic structure of reality. Theological aesthetics implies a harmonious and global understanding in which issues are viewed within the set of relationships that make up reality (Alfonso, p. 118).

Theological aesthetics implies human recognition of revelation as a manifestation of the divine and free, as well as global adherence to this aesthetic manifestation in body, soul and spirit. Aesthetics is the place of personal contact with God through perception of His glory and of the expression of divine theophany. God's glory is theologically manifested in the cross. Glory thus designates the visible manifestation of God's sovereign lordship, his divinity.

Aesthetics does not imply grasping the intramundane beauty of romanticism or of beauty understood as transcendental. Beauty and glory are epiphaneia, splendour, overwhelming and luminous revelation of the hidden and powerful foundations of being in highly expressive forms, the event of God's self-manifestation in various forms: the world, the word, history and finally man (Balthasar 1962). Aesthetics is a school focused on gaze, which does not need to be initiated by a secret doctrine; on the contrary, human beings possess a pre-understanding that enables recognition of God's manifestation. Aesthetics is the perception of God's glory that manifests itself. It is not an aesthetic theology, but a theological aesthetics, an aesthetics of the manifestation of God's glory, which happens in concrete creatures living in particular times. Among them, Bonaventure sees Balthasar de Bonaventure as a theologian touched by the glory of revelation and St. Francis of Assisi as a figure thereof. As manifestation and epiphany, theological aesthetics are inductive rather than deductive. They cannot be determined by a general (metaphysical) concept of beauty; rather, their idea of beauty must be derived from the unique manifestation of God 
in Christ. This inductive knowledge does not start from essentiality, but from expressive mediation. Real and exact knowledge of the essence of being is possible in the expressive image (Balthasar 1958).

\section{St. Francis of Assisi, Aesthetic Model in the Major Legend}

St. Francis is undoubtedly an iconic saint, a saint of "our time", one who remains relevant today. When we speak of St. Francis of Assisi, we see in him the image of a "decisive revolution in the way we feel [about] and represent the outside world" (Francastel 1956, p. 482). He himself is a model of the art of his time, as Thode (1885) noted at the end of the nineteenth century; he is a character in movies, theatre, stories and paintings (Poitrenaud-Lamesi 2018). Regardless of the accuracy thereof, there is an undeniably close relationship between Franciscan teaching and the stylistic evolution of the thirteenth century and, more specifically, between religious experience and forms of artistic life. With that said, it makes sense to assume that the model of St. Francis is presented in its theological form as an aesthetic example in itself for human expression. St. Francis invites artistic representation. His life appears as the truest human likeness of the most representative image of Jesus, who exceeds divine likeness because he is true God and true human being, the Son of God, and crucified Christ. St. Francis is a representation of Christ on the cross.

Alongside the iconic image of the cross, of a stigmatised saint, St. Francis is also represented aesthetically in literature and in the social imagination. This image relates to the crucified St. Francis, minstrel and troubadour, as defined by Chesterton (1923), who loves poverty and who cares for nature because God is reflected in it (Loewen 2013, p. 59). With his universal and ever-present aspirations, he is a very human Saint Francis. The Poverello displays a timeless, unscholarly wisdom. In our aesthetic configuration of St. Francis, we can see a paradigmatic wisdom that today would have encouraged us to love God above all else, and to be filled with gratitude for all the gifts we receive from him on a daily bsis. We see in him a human being faced with sociological parameters such that, having renounced riches to serve Christ, he was no less familiar with the temptations and trials of life. The holy founder of the Order of Friars Minor is an example that encourages us to simplify our life, to find God in all things. Simplicity is the best way to live a peaceful and fulfilled life (Verdú 2019).

However, this aesthetic representation of the saint from Assisi cannot be understood without St. Bonaventure's theological reading throughout his work and especially in his Major Legend.

\subsection{The Major Legend}

The Major Legend (Legenda Major) appears in the second part of volume VIII of St. Bonaventure's Opera omnia (Bonaventure [1260-1260] 1898b) ${ }^{1}$, forming part of a group of works on Franciscan texts. The Major Legend and related works are part of his work within the Franciscan Order as Minister General of the Order, and can be linked to his personal circumstances, as well as to the external vicissitudes that the Order of Friars Minor underwent at the time. On 23 May 1260, the feast of Pentecost, the General Chapter of Narbonne met and published the so-called Narbonenses Constitutiones (Bonaventure [1260] 1941). Sometimes considered to be the re-foundation of the Franciscan Order, it undoubtedly contributed to a reinterpretation of the spirit of the Rule at the time. This hermeneutic also touched the life of the Franciscan's holy Founder and the writing of his official biography (Legenda Major, written together with the Legenda Minor in 1263).

The ultimate intention here is to provide a unified image of the biography of St. Francis as a symbol of unified pastoral and ecclesial action within the Order. The figure of St. Francis contains a spirituality that can be defined everywhere as Franciscan, hence the decree to destroy previous biographies, which provoked a reaction from zealots. St. Bonaventure sought to save the Order from attacks from both conservatives in the Faculty of Theology and from radicals in the Faculty of Arts. His love for the Order, which was going through a difficult time, undoubtedly led him to go to Pope Clement IV on 24 November 1265 
to beg him not to appointment him as Archbishop of York. In this spirit, in addition the aforementioned biographies, at this time, his writings involved moral content and the proposal of a contemporary Franciscan forma mentis (1267-1269), including Collationes de decem praeceptis, Collationes de septem donis Spiritus sancti and Apologia pauperum.

St. Bonaventure saw the need to write a life of the Founder as part of a project to renew the Order that accompanied legislative reformulation. This project aimed to show that the Order's new legislation-the Constitutions of Narbonne-was good and in line with the spirit of the Founder. The figure of St. Francis is present throughout Bonaventure's work, both theologically and in terms of his preaching. Once the text was approved at the General Chapter of Pisa in 1263, the scriptorium of Assisi immediately ensured its diffusion, making 34 copies, one for each province. Such was its acceptance that it was declared the only official Legend of St. Francis at the General Chapter of Paris in 1266.

The Major Legend is presented as a paradigm of the Order of Friars Minor's spirit. St. Francis is the model to follow because he is the most perfect human image and likeness (imago et similitudo) of Christ, the perfect image of the Father. St. Bonaventure expresses his admiration for St. Francis and his love for Jesus Christ, implying a theological aesthetic that is reflected in its theological depth and a didactic technique that is marked by "rhetorical structure" (Cousins 1988, p. 313).

The Major Legend reflects the intellectual background of St. Bonaventure (Uribe 2008, p. 11). Thus, during the period before the General Chapter of Narbonne, around 1259, he composed important works like De triplici via, Soliloquium, De V festiv. Pueri Jesu, Tractatus de praeparatione ad missam, De perfectione vitae ad sorores, Lignum vitae, and Itinerarium. In them, we see how the Seraphic doctor aims for his brothers' spiritual edification, taking as a reference the Christian experience of St. Francis. St. Bonaventure presents the saint from Assisi as a model and symbol (Randolf 1988), that is, as a metaphysical-aesthetic exemplar of the poor and crucified Christ who is the perfect reality of God's love.

\subsection{Aesthetic Topics Related to St. Francis: Philosophical-Theological Readings}

As we have pointed out, St. Francis is in himself an aesthetic model, an iconic personality with elements not unlike a "pop" character. Several works have contributed to this dynamic, such as The Little Flowers of St. Francis, as well as certain prayers that have become hymns and gone beyond the Christian sphere. This is the case of St. Francis' own Canticle to the Creatures, also called Canticle of the Sun (Canticum Fratris Solis or Laudes Creaturarum) or the Prayer of Saint Francis (a prayer that is not present in the texts of St. Francis of Assisi). This typology, which is the result of the existential and religious simplicity of the saint from Assisi, is a reflection of the theological depth for which the Major Legend of St. Bonaventure is responsible. It is important to note that, through his study, the Seraphic doctor was able to see St. Francis' religious depth.

The semantic richness of the figure of the Poverello leads us to select relevant topics that typify his aesthetic characterisations. In this sense, we will focus on five characterisations that can be traced in the Major Legend, pointing out their aesthetic meaning and the philosophical and theological significance that St. Bonaventure assigned to them. We refer to St. Francis as a contemplator of nature, lover of poverty, an imitator of the crucified Christ, a brother of humankind and a Lord's knight and minstrel. While this topic is very profound, here we will simply make some clarifications that help understand the philosophical-theological depth of the aesthetic image of St. Francis.

\subsubsection{St. Francis: Contemplator of Nature}

Aesthetic experience is inescapably related with a sensitive openness (aisthesis) to nature. Martin Seel (1991, p. 11) points out that there is a close relationship between the recent resurgence of interest in the question of natural beauty and our contemporary relationship with nature. This relationship is all the more relevant in a world in which technical and technological mediations realised by human activity tend to instrumentalise nature, as Heidegger (1954) pointed out when he spoke of "technical capture". The preferential 
disposition of a sublime reading of natural beauty, as opposed to the aesthetic beauty of art, is essentially evident in Kant's Critique of the Faculty of Judgment (Kant 1968). Kant, from the modern point of view, establishes an aesthetic gaze in which he recovers the relationship between the beautiful and the good, between aesthetics and ethics, in such a way that natural beauty can be morally linked to the phenomenal object that is presented as the content of aesthetic appreciation. However, this aesthetic-moral relationship suffers from a lack of metaphysical mediation characteristic of the Protestantism that underlies Kantian thought. This oblivion of mediation, which is possible from the ontological perspective, is connatural, however, with a metaphysics of signification (significatio) where "the idea of 'medium' is not only not minor for St. Bonaventure, but is [also] a fundamental concept in the metaphysical scheme, since 'medium is said of that which communicates with the extremes.' This mediation has a metaphysical measure ... the metaphysical medium is ... capable of reversing in its depths the natural." (Lázaro 2019, pp. 62, 64).

The anthropological experience that underlies this question relates to the admiration that human beings have for the beauty of nature (think of a natural landscape or a sunset). St. Francis is presented as an aesthetic reference point for our admiration for and relationship with nature. This relationship first appears in a significant way in chapter $\mathrm{V}$ of the Major Legend. The young Francis left his secular life (chp. I) and began a spiritual journey based on a vocational call that led him to convert, to follow the word of God, and accept the invitation to restore the Church (chp. II). At this point in his spiritual journey, he took an initial step towards religious life (chaps. III and IV).

St. Bonaventure uses a narrative style that replaces chronological temporality with a temporality focused on union with God. This route follows the purgative, illuminative and unitive paths set out in his work De triplice via (The Threefold Way) (Bonaventure [1259-1260] 1898a) and developed in the Itinerarium mentis in Deum (Journey of the Soul into God or Journey of the Mind into God) (Bonaventure [1259] 1891). De triplice via is of a mystical and contemplative nature and proposes a path of contemplation for the soul. The Itinerarium includes three superimposed schemes, namely the contemplative, epistemological and metaphysical. This scheme is presented experientially through St. Francis in the Major Legend.

Chapter V narrates the physical suffering that Francis of Assisi endured during his infirmity. It is presented as an outward sign of the purification of his spirit after beginning his religious life. His body is a sign of weakness, but the strength with which he takes on his illness shows the reader the strength of the spirit that animates the holy founder's human nature. At the end of the chapter (n. 12), in the face of the darkness experienced in his life, the Lord gives him rest with the creatures around him, in his reading of nature. After preaching in Lombardy by the river Po, a dark night falls, causing the brothers on the road to experience anxiety. St. Francis prayed and the Lord gave them light.

This episode has two complementary sequences. On the one hand, in the face of the dark night, in a process of purgation, the Lord gives him light as he transitions on his path toward illumination. On the other hand, nature puts itself at his service, which the Seraphic doctor explains in the last paragraph of the chapter:

Consider that, at his nod, that man of admirable purity and great virtue tempered the heat of fire, changed the taste of water, brought comfort with angelic melody and was led by divine light, so that, in this way, it might be proved that the entire fabric of the universe came to the service of the sanctified senses of the holy man. (Bonaventure 1999, p. 568)

St. Bonaventure puts nature at the service of the discovery of God, as he had done in the Itinerarium (chaps. 1-3). The creation placed at St. Francis' feet during his moment of darkness is expressed in the drama of Bonaventure's theological aesthetics that reminds us that in order to survive we must escape from nothingness (darkness) and respond to the creator's call. St. Francis, a contemplator of nature, is an exemplary human model, of Christ as the cause of nature's recreation. Nature itself appears as a witness to God's power and wisdom, as the Itinerarium points out $(1,14)$, thus penetrating human nature and, in this way, in so far as created nature manifests God's justice and holiness, aesthetic sensory 
experience introduces us into the mystery of holiness. The visible realm (nature) lifts the spirit toward the invisible realm.

Chapter VIII (6-11) delves into the saint's appreciation of created nature and, at the same time, creation's subordination to St. Francis:

From a reflection on the primary source of all things, filled with even more abundant piety, he would call creatures, no matter how small, by the name of 'brother' or 'sister,' because he knew they shared with him the same beginning (n. 6). (Bonaventure 1999, p. 590)

When they had entered among them, the birds did not move from the place; and on account of the noise the birds were making, they could not hear each other saying the hours. The saint turned to the birds and said: 'Sister Birds, stop singing until we have done our duty of praising God!' At once they were silent and remained in silence as long as it took the brothers to say the hours at length and to finish their praises (n. 9). (Bonaventure 1999, pp. 592-93)

St. Francis of Assisi is presented as the new Adam, the human model of conformation to Christ, to whom nature surrenders, recapitulating the whole of creation as a privileged space for accessing the Divine Mystery.

Therefore, we should respond piously to the piety of the blessed man, which had such remarkable gentleness and power that it subdued ferocious beasts, tamed the wild, trained the tame, and bent to his obedience the beasts that had rebelled against fallen humankind. Truly this is the virtue that binds all creatures together, and gives power to all things having the promise of the life, that now is and, is yet to come. (Bonaventure 1999, p. 595)

St. Francis finds in nature not only a way to ascend toward God (via purgativa, chp. $\mathrm{V})$, but also a way for God to descend to man, once man has the experience of God as the source of creation (via illuminativa, chp. VIII) (Rivera 2008, pp. 50-51). St. Francis has an aesthetic experience: through natural experiences, he rises to God and contemplates God in them. He himself is an aesthetic model of the glory of God.

\subsubsection{St. Francis: Lover of Poverty}

In our age of opulence, there is still an aesthetic of poverty, an idealisation of material simplicity. The search for the essential has a certain mystique, giving the illusion of access to the universal. Yet this materialisation attains access to immanence on earth at best. It is a fleeting version of the aesthetic approximation at work in the Enlightenment's symbolic and cultural field, as found in Rétif de La Bretonne, who, as Philippe Barr (2012) has shown, invites readers to an aesthetic exploration of poverty. In addition to the search for material simplicity in opposition to contemporary opulence or the beginning of cursed poetry $^{2}$, we can add the tradition initiated by Diogenes, namely poverty as a sign of honest philosophy. The beggar philosopher, following Socrates' example, is situated in a cynical position from which he turns the difficulty of enduring poverty into an opportunity to ridicule splendour. The philosopher exalts poverty as a condition of his honesty. Beyond the destitution it entails in terms of vital and sociological aspects, poverty is presented for its existential qualities.

Saint Francis, the Poverello (poor person), appears as an aesthetic model for the twenty first century. Within an ideological reading of contemporary ecological and economic crises, Francis of Assisi appears as the emblematic figure of an ethic of simplicity and frugality expressed through an aesthetic of poverty (Poitrenaud-Lamesi 2018). However, this aesthetic image is disfigured, trivialised and, what is worse, used ideologically, if we do not take into account its theological and philosophical depth. Such a characterisation has a central place in the Major Legend, in relation and in tune with the topos of nature discussed in the previous section.

Poverty is an essential element in conversion and is essential in the purgative path of St. Francis' spiritual itinerary, thus appearing in chapter V, which, as we have seen, 
corresponds to his first spiritual stage. This chapter (n. 1-2) opens by describing in orderly detail the austerity of St. Francis' life, including how it impacted his eating and drinking, his clothing, and the way he slept. The purpose of this austerity appears in n. 3: "Unbending in discipline he stood upon his guard, taking the greatest care to preserve purity of both soul and body" (Bonaventure 1999, p. 562).

In chapter VII, on his path to divine union in an illuminating moment, poverty is the principal foundation of all the virtues (Paupertas est primarium fundamentum omnium virtutum), as defined by St. Bonaventure in his sermon Dominica de albis (1901, p. 298).

"Holy poverty" (Bonaventure 1999, p. 554, chp. IV, 7) is first and foremost a religious experience, and it encourages an apostolic and evangelical way of life based on spirituality (Lambert 1961; Emmanuelli and Feuillet 2000). But, starting from the work of the first masters of the Franciscan Order, poverty is also an element of theological and philosophical reflection that follows an ad intra path, and is a catalytic concept of the Christian being found in the Minor, as well as ad extra, insofar as it is a novel expression of a new form of religiosity in a century of social and economic transformation (Manselli 1995). Thus, St. Bonaventure was compelled to explicitly develop the virtue of poverty, to explain and to defend it as a form of virtuous living in the life of the Church (Bussum 1959). The domina Paupertate (Lady Poverty) of the allegorical poem Sacred Exchange between St. Francis $\mathcal{E}$ Lady Poverty (Sacrum commercium beati Francisci cum domina Paupertate) (Armstrong et al. 1999) is the literary expression of the Apologia paupertatis (Manselli 1977; Mattia 1988).

Poverty as a concept that energises St. Bonaventure's thought. It relates to his responsibilities within the Order and the Franciscan way of life, as well as affects how he does philosophy. This philosophical attitude (led by Socratism and Cynicism) is completed by a profound theological one and interior disposition. In this sense, the St. Francis of the Major Legend is a reflection of the attitude found in the Itinerarium. It is the speculation of the poor man in the desert-speculatio pauperis in deserto-(Prunières 1972), the investigation of a person who accepts the virtue of poverty and rejects pride, that is to say, who is capable of purging himself in order to reach, little by little, something similar. Thus, the Bonaventurian booklet includes the three classical ways of interiority and mysticism-it starts from poverty and an invocation of peace (proper to the perfective way) to end in the contemplative way that unites the threads of the Major Legend.

St. Francis, lover of poverty, is the visible, incarnated sign of the desire for perfection to which the true wisdom that is God's love leads us. The Poverello characterised by St. Bonaventure is a model of humanity on the way; he knows himself to be poor and discovers in his lack the most suitable anthropological state for being capable of God (capax Dei). This is the conceptual foundation of the philosophy of poverty as an attitude. St. Bonaventure uses thought that had already elaborated, more or less consciously, and structures it through his personal genius and Franciscan spirit.

The Seraphic Doctor inherited a vision of the philosophy of poverty explained theologically in the patristic period (St. John Chrysostom, St. Augustine, etc.). To this perspective, he adds philosophical development of poverty where poverty is shown as the necessary impulse for the human being who is on the way (in via). Poverty is the starting point for the philosopher who seeks the inner master, for the theologian who delves into a spiritual itinerary as an image of God, and for the mystic on his journey along the path of enlightenment, until he reaches Truth, Likeness and Mystical Union.

\subsubsection{St. Francis: An Imitator of the Crucified Christ}

St. Francis conforms to the poor and crucified Christ. The crucifixion is a central theme in the Christian faith, as well as holding a special place in art. The cross is an expression of suffering, but also of triumph over death, as can be seen in the early Middle Ages in the image of the Christ triumphant over death with his eyes open. Artists in the late Middle Ages, however, depicted the crucified Christ as dead or suffering. The Christ contemplated by St. Francis is the triumphant Christ of San Damiano's crucifix (twelfth century), while the suffering Christ (patiens) is found in Giotto's Franciscan frescoes (fourteenth century). 
It is a path towards the aesthetics of pain and overcoming it; over time, especially from the Renaissance onwards, this path acquired an inner dimension, a mystical intimacy (Bœspflug and Fogliadini 2019). The cross of Christ is an expression of the humility of God incarnate, a humility that Nikola Sarić (Christian sacral artist) reveals in the twenty first century with his work Christâne (Christ with an ass's head), a bronze statue inspired by graffiti from Alexamenos (third century) found in Rome). The cross does not leave the viewer unmoved and is an aesthetic element (Bœspflug and Fogliadini 2019, pp. 380-83).

In the previous points, especially when looking at nature, we have noted how the saint from Assisi represents, in turn, a reading of the world in its ontological and semantic depth. This ontological image of the aesthetic dimension is especially notable in his conformation to Christ. This conformation gives meaning to all of the above. St. Francis, as the image of the crucified Christ (Muscat 1989), inspires and is a source for contemplating the beauty of creation as the beauty of divine harmony. St. Bonaventure teaches us in chapter XIII (The Sacred Stigmata) the role that Christ must play in the life of the Christian, a reflection that he himself experienced in his retreat on Mount Alvernia, which he related in his Itinerarium mentis in Deum. St. Francis went through a period of retreat, of Exodus (forty days); In the mountains (like Moses on Mt. Tabor), he experienced transfiguration from the image of transformation before embracing the cross of Christ:

After true love of Christ transformed the lover into His image, when the forty days were over that he spent in solitude as he had desired, and the feast of St. Michael the Archangel had also arrived, the angelic human Francis came down from the mountain, bearing with him the likeness of the Crucified, depicted not on tablets of stone or on panels of wood carved by hand. (Bonaventure 1999, p. 634, chp. XIII, 5)

Transformed, a path towards the care and contemplation of nature becomes clear. The world is a song, an expression (Bonaventure 1999, p. 644, chp. XIV, 6). It makes sense and drives the love of poverty. The related theological depth is aesthetically elevated. The Poverello shows a special interest in "imitation" of Jesus Christ's poverty and humility. But St. Francis of Assisi does not just imitate by adopting an attitude of imitation, but rather his heart is always open to creation, which "sings" to God. An attitude open to contemplation of nature presupposes the harmony of creation, which became a prayer and way of life in the Canticle of Creatures, an ode to divine harmony (Delio 1992). St. Francis of Assisi assimilates, in a vital attitude, contemplation of the beauty in the world in order to attain divine beauty through mystical contemplation. God is power, strength, and goodness, as well as, undoubtedly and based on his humble heart, He is harmony and beauty incarnated in the Word.

Beginning with his conversion, Bonaventure presents the Poverello as an exemplar and guide to evangelical perfection. The New Testament perspective predominates in the figure of St. Francis. The various qualifications he receives in the Mayor Legend from the Seraphic doctor carefully designate the exemplary nature of his life as an example of relationship with God and fraternal relationship with all human beings. This relationship is realised through following Christ and a life of penance. His link with Christ-the Mediator-is clear and is reflected in the 64 Christological titles with which the Seraphic Doctor describes the founder (Uribe 2005, p. 122). And it is also evident in his own personal journey. St. Francis was a convert and, on the day he made his conversion public, he did so with a gesture of great Christological flavour. Indeed, he undressed before the Bishop-Nudam crucem nudus sequar, nudum Christum nudus sequere (Châtillon 1974), thus announcing his conformation to Christ; this scene culminated in his stigmatisation. The Pauline "new man" makes the very signs that are a priori a scandal and folly (signs including stripping down and receiving the stigmata—being "stigmatised"), yet are the very signs that Christ received. The burning bush in which God manifested himself becomes the lignum vitae (the cross of Christ), where Christ shows the love of the Triune God who is and communicates himself to human beings, a foretaste of the eschatological display (hence the Tau, the sign of human conversion to Christ). 
Purification and contemplation become a way toward union. Let us recall that St. Francis expresses the symbol of the cross in his person, a similarity with infinite reality, and, at the same time, implying that "he who is" is a communicator.

\subsubsection{St. Francis: Brother of Humankind}

Twenty-first century individuals find in universal brotherhood not only a utopian slogan, but also an aesthetic moment of sociability. This is not surprising if we recall that twenty-first century human beings are neo-Romantic. This disposition reinforces, in a digitised and ephemeral form, the aesthetics of sociability of which Friedrich Shiller wrote, since aesthetics and anthropology were already closely related in philosophy before Schiller (Heinz 2004). It is this aesthetic sentiment that leads one to consider Rousseau an a priori agreeable character.

Fraternity in the life of St. Francis is not an aesthetic abstraction, however. Rather, it is a concrete gift from God to each person. The Poverello of Assisi, starting from the experience of conformation to Christ as the axis of his existence, both in his preparation and in his projection, extends universal fraternity to all creation. Cosmic fraternity makes sense in fraternal intimacy with Christ and in the fraternity that is born of aesthetic theology: reality is significative and unites us as traces, and especially as images, of God. The other is always a sacramental reality of God, whether as a vestige with nature (via purgativa), or as an image in the brotherhood of humanity (via illuminativa), or as a likeness of God (via unitiva).

The beauty of creation is born of the charity that unites all creation:

In beautiful things he contuited Beauty itself and through the footprints impressed in things he followed his Beloved everywhere, out of them all making for himself a ladder through which he could climb up to lay hold of him who is utterly desirable. With an intensity of unheard devotion he savored in each and every creature - as in so many rivulets - that fontal Goodness, and discerned an almost celestial choir in the chords of power and activity given to them by God, and, like the prophet David, he sweetly encouraged them to praise the Lord. (Bonaventure 1999, pp. 596-97, chp. IX, 1)

Francis' universal brotherhood has its origin in the profound experience of brotherhood with Christ and his desire to make him known, his missionary fervour. As a "man of God", he had learned not to seek his own interests, but to seek the salvation of others. And this was born of his desire to die for and be with Christ, which is why his main concern was to be free from everything in the world, so that not even the slightest speck of dust could cloud the serenity of his soul. He remained impervious to all external noise, and he put all his soul into keeping his external senses in check and mastering the movements of his mind in order to give himself to God alone.

St. Francis of the Major Legend expresses this profound humanity in conversation with God in solitude:

The man of God remaining more alone and at peace would fill the forest with groans, water the places with tears, strike his breast with his hand, and, as if finding a more secret hiding place, would converse with his Lord. There he replied to the Judge, there he entreated the Father, there he conversed with the Friend. (Bonaventure 1999, p. 607, chp. X, 4)

Bonaventure recapitulates the aesthetic figure of St. Francis. The philosophy of the epistemological and anthropological movement of ascent, together with the theology of the image, are placed at the service of a reading of the Founder who was on a journey (itinerary) towards divine unification. The new Franciscan brotherhood loves nature in poverty, leading to the extraordinary fact that, at the beginning of their Franciscan life, the Minors "abandon the world" to conform to Christ (Esser 1976, p. 35). In this abandonment, which manifests itself in contact with the solitude of abandonment to God (giving oneself 
to God alone), a life of conformity to the Gospel begins, which is presented as the norm of fraternity.

\subsubsection{St. Francis: Lord's Knight and Minstrel}

In 1959, the radio programme "Spectral Analysis of the West" (Analyse spectrale de $l^{\prime}$ Occident) devoted a series to the Gothic civilisation, in which it broadcast a reading of a text by G. K. Chesterton on St. Francis of Assisi, "the Lord's minstrel." This aesthetic characterisation had already appeared in Auguste Bailly's work The Divine Minstrels: A narrative of the life of Saint Francis of Assisi with his companions (1909). Saint Francis is the character of the aesthetics of joy and commitment, a Christianized valiant Arthurian knight.

St. Francis of Assisi is the hero of contemplative action, of apostolic action, an archetype of a new knight. St. Francis is a young person who wishes to be a knight, to convert his life into a life of self-giving within the world:

Shortly after he had embarked on his journey and had gone as far as the neighboring city, he heard the Lord speaking to him during the night in a familiar way: 'Francis, who can do more for you, a lord or a servant, a rich person or one who is poor?' When Francis replied that a lord and a rich person could do more, he was at once asked: 'Why, then, are you abandoning the Lord for a servant and the rich God for a poor mortal?' And Francis replied: 'Lord, what do you want me to do?'. (Bonaventure 1999, p. 533, chp. I, 3)

In his quest for conversion, he begins to change the idea of the knight: as opposed to the "proud and unbearable knight," Francis shows that patience is superior. If pride leads to vain victory, patience brings us reconciliation, to the knight's true virtues. It is precisely this vision of the "knight" that initiates his conversion. The knight of Christ, Bonaventure points out in the Major Legend, examines perfection and conquers himself; he does not go in search of treasure, but rather seeks out the leper. The new knight seeks peace over war, but does not flee in the face of difficulties; he is a knight because he seeks to fulfill the demands of virtue (Felder 1941). As a knight of Christ, solitude arises: "One of those days, withdrawn in this way, while he was praying and all of his fervor was totally absorbed in God, Christ Jesus appeared to him as fastened to a cross" (Bonaventure 1999, p. 534, chp. I, 5). The cross is an honour for the "knight of Christ" (Christi miles) (Bonaventure 1999, p. 533, chp. I, 5) of the Gospel (2 Tim 3,3); as such, St. Francis bears the fruit of the solitude (of recollection) of knowing that "God alone is enough".

This Franciscan experience runs through the spirit of the minors, and was enriched by theological topos that go from the School of St. Victor to the Halesian compilation, passing through St. Bonaventure's theological-mystical formulations (and those of pseudoBonaventurians). It influenced Ramon Llull's knight and transformed the virtues of fifteenth-century Castilian and Portuguese courts recalled in literature like the Book of Christian Chivalry by Jaime de Alcalá (1515), in the knight transformed in Manresa (1522) as can be seen in the Spiritual Exercises of Ignatius of Loyola (1541; 1548), and in the miles (militis christiani) and the knight's transformation in Erasmus' Enchiridion (1503, printed in Alcalá in 1525). Through these formulations, the Platonic-Christian philosophical tradition emerges. Francis of Assisi is the new knight of the new round table: Francis and his companions.

The chivalrous image of St. Francis's secular life in the Major Legend (Bonaventure 1999, p. 532, chp. I, 3) is transformed into a knight of Christ (Bonaventure 1999, p. 533, chp. I, 4) as this spirit becomes beauty and beauty is sung. After performing his first deed as a knight of Christ, as a soldier of divine beauty, giving his clothes to a leper, "he began, therefore, filled with wonder and joy, to sing praises to the Lord, while proposing, because of this, to embark always on the greater" (Bonaventure 1999, p. 534, chp. I, 5). The role of music, of the poetry of song in Francis of Assisi appears especially in Celano's biographies, but, as we have seen, also plays a role in St. Bonaventure: it symbolises the joy experienced in inner transformation. Chapter 2 (Bonaventure 1999, p. 539, chp. II, 5) narrates how St. Francis, enthusiastic about the beginning of his transformation that culminates in his 
conformation to the Christ, a knight whose mission is to proclaim Christ, sings to the Lord in the forest ("While Francis, the man of God, was making his way through a certain forest, singing with glee praises to the Lord in French") and when he is beaten up by robbers because of it ("After they left, he jumped out of the ditch, and exhilarated with great joy, he began in an even louder voice to make the woods resound with praises to the Creator of all."). The troubadour is a singer of love (Dante's Stil nuovo) in the same way that the minstrel alleviates life's heaviness with his recitals and joy. They are artists of free speech who invent a new aesthetic, the "art of trobar". The domna (lady) is placed at the centre of lyrical creation: lady poverty. Dante Alighieri (Divina commedia. Paradiso, Sing XI, vv. 60-66) describes this when he says that poverty, having lost her first husband, finds her second husband in St. Francis:

Questa, private del primo marito,

mille e cent'anni e più dispetta e scura

fino a constui si stette senza invito.

Song is also St. Francis' aesthetic expression, a model spiritual itinerary that culminates in conformation to Christ, positively actualising the flight of the neo-Platonic soul, which is capable of reaching the supernatural, a place much richer than the Ithaca of Odysseus. He who has placed himself at the service of Christ (the knight of Christ) and assumes his mission with joy, receives the joy of seeing that nature, reality, the world in short, is not negative when seen from the perspective of the spiritual union.

\section{Conclusions}

The figure of St. Francis of Assisi has had significant impact. The thematisation thereof is very broad and affects his very person. St. Francis of Assisi goes beyond a concrete "flesh and blood" person, in other words, his evangelical spirit surpasses his earthly manifestation. The figure of the Poverello is full of the living, historical and theological spirit of St. Francis, inspiring many ideas within the work and perspective associated with the Franciscan School.

St. Francis is thus a traveller, a human on a journey: the hierarchical man. His life represents the mystical ways: purgative (until conversion), illuminative (until the approval of the Rule) and unitive (the path of unification with Christ crucified). St. Francis received this by express divine grace. A life of conversion, and of union, is re-edited.

Understanding the philosophical and theological foundations of St. Francis as St. Bonaventure described him helps us go beyond stereotypes and more deeply understand affirmations that are not without aesthetic expression. For example, Jacques Le Goff (1999, p. 39) described him as follows:

Friend and brother of all creatures and of the whole of creation, he showed so much concern, so much fraternal understanding for all, so much charity in the highest sense, that is to say, love, that history has given him, as if in exchange, the same affectionate and general sympathy and admiration. All those who have spoken and written about him-Catholics, Protestants, non-Christians, nonbelievers - have been touched and often fascinated by his charm.

The aesthetic evocations first expressed in Giotto's work and then renewed over time make sense in the context of the Major Legend and its theological depth. In light of this reference, we cannot fail to mention a third aspect related to Francis of Assisi, namely his almost infinite capacity to inspire artistic and vital projects.

St. Francis continues to entice artists, but his simplicity is not simplism. His aestheticism is profound theology and philosophical ascent. References to him reveal Francis of Assisi, the saint, the Poverello, as an example of a man on a pilgrimage in search of ethical responsibility in the world around him and in his inner self, of a man who feels his capacity for God and has authentic access to the divine Mystery (Cicarelli 1974, pp. 108-9).

Understanding the figure of St. Francis in the Franciscan tradition implies familiarity with St. Bonaventure's underlying theological references, while understanding of St. 
Bonaventure's profound theological speculation can only be had through analysis of the saint from Assisi's life experience and ideals.

Author Contributions: Conceptualization, M.L.P., and E.A.I.; methodology, M.L.P., and E.A.I.; investigation, M.L.P., and E.A.I.; writing—original draft preparation, M.L.P., and E.A.I.; writing—review and editing, M.L.P. and E.A.I., All authors have read and agreed to the published version of the manuscript.

Funding: This research was funded by Universidad Bernardo O'Higgins, Chile.

Institutional Review Board Statement: Not applicable.

Informed Consent Statement: Not applicable.

Conflicts of Interest: The authors declare no conflict of interest.

\section{Notes}

We will follow the English edition (Bonaventure 1999).

The cursed poets movement emerged in nineteenth-century France, when a series of poets and writers began to break established rules in search of beauty where no one else saw it. They took on a bohemian lifestyle because they wanted to live their life to the fullest without regard for possibly disrupting French convention.

\section{References}

Aquinas, Thomas. 1889. Pars prima Summae theologiae. In Opera Omnia. Edited by Leonis XIII. Roma: Typographia Polyglotta, vol. 5. First published 1265.

Bailly, Auguste. 1909. The Divine Minstrels: A Narrative of the Life of Saint Francis of Assisi with His Companions. New York: Charles Scribner. Balthasar, Hans Urs von. 1958. Dieu a parlé un langage d'homme. In Parole de Dieu et Liturgie, 3e Congrès National du C.P.L. Paris: Cerf, pp. 71-103.

Balthasar, Hans Urs von. 1962. Herrlichkeit eine theologische Ästhetik Bd. 2. Fächer der Stile Teil 1 Klerikale Stile. Einsiedeln: Johannes.

Barr, Philippe. 2012. Rétif de la Bretonne Spectateur Nocturne: Une esthétique de la pauvreté. Amsterdam: Rodopi.

Bœspflug, François, and Emanuela Fogliadini. 2019. La Crucifixion dans l'art. Un sujet planétaire. Paris: Bayard.

Bonaventure, St. 1891. Itinerarium mentis in Deum. In Opera Omnia. Edited by P. P. Colegii a S. Bonaventura. Quaracchi: Ad Claras Aquas, vol. 5, pp. 293-316. First published 1259.

Bonaventure, St. 1898a. De triplice via, alias incendium amoris. In Opera Omnia. Edited by P. P. Colegii a S. Bonaventura. Quaracchi: Ad Claras Aquas, vol. 8, pp. 3-27. First published 1259-1260.

Bonaventure, St. 1898b. Legenda maior sancti Francisci. In Opera Omnia. Edited by P. P. Colegii a S. Bonaventura. Quaracchi: Ad Claras Aquas, vol. 8, pp. 504-64. First published 1260-1263.

Bonaventure, St. 1901. Sermones de tempore. In Opera Omnia. Edited by P. P. Colegii a S. Bonaventura. Quaracchi: Ad Claras Aquas, vol. 9, pp. 23-461.

Bonaventure, St. 1941. Constitutiones Generales Ordinis fratrum minorum. Edited by M. Bihl. Rome: Archivum Franciscanum Historicum, pp. 34: 13-94; 284-358. First published 1260.

Bonaventure, St. 1999. The Major Legend of Saint Francis (1260-1263). In Francis of Assisi: Early Documents, Vol. 2, The Founder. Edited by Regis J. Armstrong, J. A. Wayne Hellmann and William J. Short. New York, London and Manila: New City Press, pp. 525-649.

Bruyne, Edgar de. 1947. L'esthétique du Moyen Âge. Louvain: Éditions de l’Institut supérieur de philosophie.

Bussum, Vito da. 1959. Il movimento di povertà di s. Francesco e quello di Pietro Valdo. L'Italia francescana 34: 225-33, $299-307$.

Châtillon, Jean. 1974. Nudum Christum nudus sequere. Note sur les origines et la signification du thème de la nudité spiritual dans les écrits de Saint Bonaventure. In S. Bonaventura 1274-1974. Edited by Jacques Guy Bougerol. Grottaferrata: Collegio S. Bonaventura, vol. 4, pp. 719-72.

Chesterton, Gilbert Keith. 1923. Saint Francis of Assisi. London: Hodder and Stoughton.

Cicarelli, Marciano M. 1974. San Bonaventura Maestro di Vita Spirituale. Montecalvo Irpino: Cenacolo bonaventuriano.

Cousins, Herbert. 1988. The image of St. Francis in Bonaventure's Legenda Maior. In Bonaventuriana. Miscellanea in onore di Jacques Guy Bougerol OFM. Edited by Francisco de Asís Chavero. Roma: Edizioni Antonianum, vol. 1, pp. 311-21.

Delio, Illia. 1992. The Canticle of Brother Sun: A song of Christian mysticism. Franciscan Studies 52: 1-22. [CrossRef]

Eco, Umberto. 1986. Art and beauty in the Middle Ages. New Haven: Yale University Press.

Eco, Umberto. 2009. Arte e bellezza nell'estetica medievale. Milano: Bompiani.

Emmanuelli, Xavier, and Michel Feuillet. 2000. Célébration de la pauvreté. Regards sur François d'Assise. Paris: Albin Michel.

Esser, Kajetan. 1976. La Orden franciscana. Orígenes e ideales. Burgos: Editorial. Aránzazu.

Felder, Hilarin. 1941. Der Christusritter aus Assisi, der hl. Franziskus. Zürich-Altstetten: B. Götschmann.

Francastel, Pierre. 1956. L'art italien et le rôle personnel de saint François. Annales. Économies, Sociétés, Civilisations 11: 481-89. [CrossRef] 
Galeffi, Romano 1976. Relazione tra arte e teologia in S. Bonaventura da Bagnoregio. In San Bonaventura maestro di vita francescana e di sapienza cristiana: Atti del Congresso internazionale per il 7 centenario di San Bonaventura da Bagnoregio, Roma, 19-26 settembre 1974. Alfonso, Pompei, ed. Roma: Pontificia Facoltà Teologica San Bonaventura, vol. 3, pp. 117-31.

Gonzalez, Valerie. 2001. Beauty and Islam. Aesthetics in Islamic Art and Architecture. London: I.B. Tauris.

Goullet, Monique. 2011. L'esthétique de la brièveté dans l'hagiographie latine médiévale. In Faire court: L'esthétique de la brièveté dans la littérature du Moyen Âge. Edited by Catherine Croizy-Naquet, Laurence Harf-Lancner and Michelle Szkilnik. Paris: Presse de la Sorbonne Nouvelle, pp. 35-64.

Heidegger, Martin. 1954. Die Frage nach der Technik (1953). In Gesamtausgabe Band 7: Vorträge und Aufsätze (1936-1953). Edited by Friedrich-Wilhelm von Herrmann. Frankfurt am Main: Vittorio Klostermann, p. 7.

Heinz, Marion. 2004. La beauté comme condition de l'humanité. Esthétique et anthropologie dans les « Lettres sur l'éducation esthétique ». Revue Germanique Internationale 22: 133-44. [CrossRef]

Kant, Immanuel. 1968. Kritik der Urteilskraft. In Kant, Werke, Band 8. Darmstadt: Wissenschaftliche Buchgesellschaft.

Lambert, Malcolm David. 1961. Franciscan Poverty: The Doctrine of the Absolute Poverty of Christ and the Apostles in the Franciscan Order, 1210-1323. London: Church Historical Society Publications.

Lambert, Adélaïde. 2017. Hagiographie et mise en prose au XIIIe siècle. L'exemple de Barlaam et Josaphat. Le Moyen Âge CXXIII: 507-26. Lázaro, Manuel. 2019. Más allá de la quiditas: Reflexiones sobre el Proyecto metafísico bonaventuriano. Cauriensia 14: 49-80. [CrossRef] Le Goff, Jacques. 1999. Saint François d'Assise. Paris: Gallimard.

Liedo, Belén, and Jon Rueda. 2021. In defence of posthuman vulnerability. Scientia et Fides 9: 215-39. [CrossRef]

Lobato, Abelardo. 1999. El horizonte estético del hombre medieval: La perspectiva tomista. Revista Española de Filosofía Medieval 6: 57-68. [CrossRef]

Loewen, Peter W. 2013. Music in Early Franciscan Thought. Leiden: Brill.

Lomba, Joaquín. 1999. Presentación. Revista Española de Filosofía Medieval 6: 11-24. [CrossRef]

Manselli, Raoul. 1977. La povertà francescana e san Bonaventura. Doctor Seraphicus 24: 43-61.

Manselli, Raoul. 1995. La povertà nella vita di Francesco d'Assisi. In Francesco e i Suoi Compagni. Roma: Istituto Storico dei Cappuccini, pp. 201-22.

Mattia, Silvana di. 1988. San Bonaventura e la povertà francescana (L' “apologia pauperum”). In Bonaventuriana. Miscellanea in onore di Jacques Guy Bougerol ofm. Edited by Francisco de Asís Chavero. Roma: Edizioni. Antonianum, vol. 2, pp. 417-30.

Muscat, Noel. 1989. The Life of Saint Francis in the Light of Saint Bonaventure's Theology on the "Verbum Crucifixum". Roma: Pontificium Athenaeum Antonianum.

Poitrenaud-Lamesi, Brigitte. 2018. Imaginaires et Pauvreté: François d'Assise dans la Création Contemporaine. Paris: Istituto Italiano di Cultura.

Prunières, Louis. 1972. Itinéraire de l'esprit en Dieu. II: Spéculation du Pauvre dans le désert. Études Franciscaines 22: $39-68$.

Puerta, José Miguel. 1997. Historia del pensamiento estético árabe. Al-Andalus y la estética árabe clásica. Madrid: Akal.

Randolf, Daniel E. 1988. Symbol or Model? St. Bonaventure's use of St. Francis. In Bonaventuriana. Miscellanea in onore di Jacques Guy Bougerol ofm. Edited by Francisco de Asís Chavero. Roma: Edizioni. Antonianum, vol. 1, pp. 55-62.

Rivera, Enrique. 2008. Acercamiento al alma de San Francisco. Salamanca: Tenacitas.

Sacred Exchange between St. Francis \& Lady Poverty. 1999. In Francis of Assisi: Early Documents, Vol. 1, The Saint. Edited by Regis J. Armstrong, J. A. Wayne Hellmann and William J. Short. New York, London and Manila: New City Press.

Seel, Martin. 1991. Eine Ästhetik der Natur. Francfort-sur-le-Main: Suhrkamp.

Thode, Henry. 1885. Franz von Assisi und die Anfünge der Kunst der Renaissance in Italien. Berlin: Grote.

Uribe, Fernando. 2005. El Francisco de Buenaventura. Observaciones después de leer la «Leyenda Mayor». Carthaginensia 39: 109-42.

Uribe, Fernando. 2008. El Francisco de Buenaventura. Lectura de la Leyenda Mayor. Salamanca: Tenacitas.

Verdú, Ignacio. 2019. Amor y metafísica. Una reflexión acerca de la filosofía primera. Cauriensia 14: 117-30. [CrossRef]

Veyrard-Cosme, Christiane. 2003. Éloge du saint, louange de Dieu dans la littérature hagiographique latine du Haut Moyen Âge. Lalies 24: 7-36. 